REPORTS OF MORPHOLOGY
$\begin{gathered}\text { Official Journal of the Scientific Society of Anatomists, } \\ \text { Histologists, Embryologists and Topographic Anatomists } \\ \text { of Ukraine } \\ \text { journal homepage: https://morphology-journal.com }\end{gathered}$

\title{
Contradictory views on the acquired and congenital etiology of pilonidal disease
}

\section{Konoplitsky V.S., Shavliuk R.V., Shavliuk V.M.}

National Pirogov Memorial Medical University, Vinnytsya, Ukraine

\section{ARTICLEINFO}

Received: 23 December, 2019

Accepted: 30 January, 2020

UDC: $611.711 .8 . .616-053-089$

\section{CORRESPONDING AUTHOR}

e-mail: shavliuk.ruslan@gmail.com

Shavlyuk R.V.

\begin{abstract}
Pilonidal disease is a pathology that was first described more than 100 years ago. However, it still remains the subject of discussion, because there is still no clear unambiguous definition of this pathology, nor its well-known etiology. Despite the large number of developed and substantiated theories, there are still two opposing views on the cause of pilonidal disease. Some scientists are supporters of the "congenital" theory, others - the theory of acquired origin. However, this does not clarify the ultimate goal of these studies: to develop optimal treatment tactics. The purpose of the work is to clarify the data on the etiology of pilonidal disease in children. The study is based on the results of treatment analysis of 37 children diagnosed with "pilonidal disease" who were hospitalized in the Department of Emergency Surgery of Vinnytsia Regional Children's Clinical Hospital, of which boys - 26, girls - 11. The mean age of patients was $16.4 \pm 0.4$ years. Histological sections of tissue samples were stained with hematoxylin and eosin. Microscopy and creation of a photo archive of histological specimens were performed using a light microscope OLIMPUS BX 41 at a magnification of 100 and 200, in the software environment "Quick PHOTO MICRO 2.3". The study found that there are significant differences in the histological structure of pilonidal cysts in children and adults. In pediatric patients, mesenchymal tissue was found, which is not typical for this group of patients. It was also found that the cavity of the pilonidal cyst in children is covered with a multilayered squamous non-keratinizing epithelium, and there is almost no granulation tissue. In our opinion, pilonidal disease is a polyetiological disease, the main cause of which is the congenital features of the organism, which are realized due to socio-economic and environmental factors.

Keywords: pilonidal disease, children, etiology, morphology.
\end{abstract}

\section{Introduction}

Pilonidal disease (PD), despite more than a century of history as a pathology described by Anderson A. in 1847, still has a large number of "white" spots. These include many things, from a clear definition of the pathology and ending with the rehabilitation of patients after surgery. One such dilemma is the question of the etiology of this disease. Most researchers in the post-Soviet space believe that pilonidal disease is purely congenital and manifests itself after the birth of a child [7, 9, 15, 17]. As for most European and American researchers, they prefer the acquired genesis of the disease, which is realized through the influence of environmental and social factors. But is such a clear division justified enough?

In favor of the congenital genesis of the development of pilonidal disease testifies the fact that some researchers in its development note a hereditary predisposition in 10.4-
$38.0 \%$ of cases $[1,13,16]$. In addition, Dool D. in 2009 , determined that PD with a frequency of up to $12 \%$, is observed in the first line of kinship [6]. In addition, the most common are young and working age - 15-30 years patients, which is close to the idea of congenital genesis of this pathology [7].

Another interesting assumption was made in 1931 by Stone H.B., who presented pilonidal disease as an analogy of uropygial glands. These glands are secondary sexual characteristics of birds, and in humans - the process of ectodermal layer of the outer ear and breast [1].

This theory was supported by Kallet H.I. in 1936, putting forward the data of his observations. They stated that the manifestation of the disease occurs directly during puberty, ie, during the development of secondary gonads under the influence of pituitary hormones [2]. 
The congenital theory of pilonidal disease has been described by many scientists, but the main and most important role is given by Bascom J. (1980), who formulated and described the follicular-retention theory of disease development and trichogenic-pump mechanism of secondary fistula $[2,10]$. The essence of the theory is that the hair found in the cavity of the pilonidal cyst is the result of periodic occurrence of negative pressure in it in response to relaxation and tension of the gluteal muscles [5, 16]. This theory was most actively supported and developed by Karydakis G.E., who in 1992 published a work based on the analysis of the course of the disease and the treatment of 6000 patients with pilonidal disease [8].

However, it should be noted that all researchers from both "camps" see an important role in the constitutional features of the body, such as: the depth of the intergluteal fold and the condition of the skin in it, the structure of hair and hair distribution, shape and size of the pelvis, obesity etc. These factors should be considered as features of the constitution of each individual, which remain stable throughout life. This confirms that pilonidal disease should be considered as a multifactorial pathology, which is realized under the influence of various causes. However, the constitutional type of structure of the organism is an innate feature and is provided by genetic potential. Also, in completely healthy children (including newborns) during the examination there are often funnel-shaped and fistulalike formations in the intergluteal region, which are visually similar to the primary fistula courses (Fig. 1). But, although the constitution of the organism is stable throughout life, it is realized under the influence of environmental factors. These include physical factors (physical activity), as well as socio-economic factors that play the greatest role in adolescence (nature of work and study, diet, living conditions, diseases) [12]. Therefore, to consider pilonidal disease purely as a congenital or acquired pathology is not correct.

However, the question of what the main mechanism

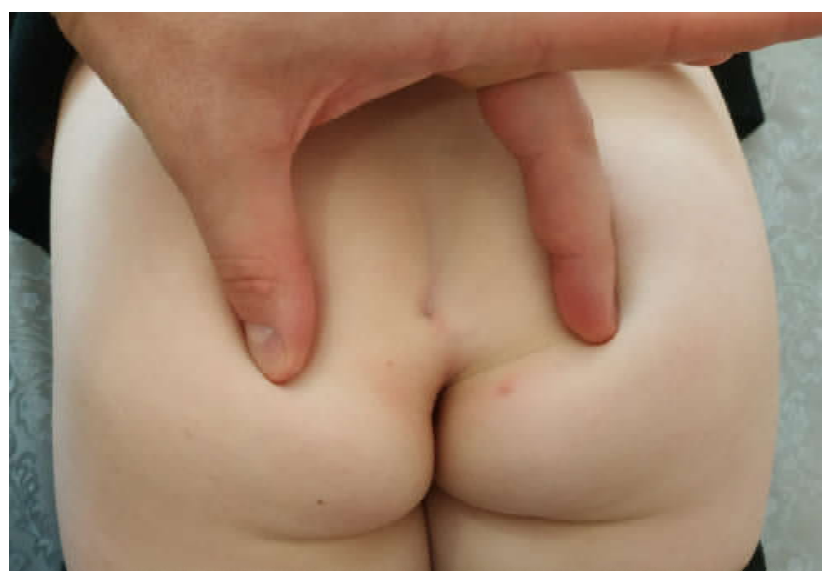

Fig. 1. Patient $\mathrm{H}$., age 3 years. Funnel-shaped retraction in the area of the intergluteal fold, detected during a preventive examination. leads to the development of pilonidal disease - congenital or acquired - remains open.

Purpose of study: to clarify the data on the etiology of pilonidal disease in children.

\section{Materials and methods}

One of the theories of the development of PD pathology is based on the fact that the epithelium, which is found in the pilonidal cyst, is the final variant of the mechanism of formation of the ectodermal layer. Taking it as a basis, we performed a histological study of fragments of skin and subcutaneous fat containing pathological substrate (pilonidal cyst). These tissue arrays were removed intraoperatively. After the examination, an assumption was made about the congenital origin of the pathology due to a violation of cell determination. Such changes are most pronounced at the stage of tissue development from the material of embryonic rudiments due to tissue determination in the sacrococcygeal region.

The study is based on the results of the analysis of the treatment of 37 children diagnosed with "pilonidal disease" who were in the pediatric surgery clinic of National Pirogov Memorial Medical University, Vinnytsya from 2010 to 2017. The average age of patients was $16.4 \pm 0.4$, the gender distribution was as follows: there were 26 boys and 11 girls.

In order to compare the morphological structure of the pilonidal cyst in adults, 17 samples of removed tissues were studied according to the archives of the Vinnytsia Regional Pathology Bureau. Sections of intraoperatively removed tissue samples for the study were stained with hematoxylin and eosin. Microscopy and creation of a photo archive of histological specimens were performed using a light microscope OLIMPUS BX 41 at magnification $\times 100$ and $\times 200$, in the software environment "Quick PHOTO MICRO 2.3".

\section{Results}

After histological examination of the samples we found that in tissue samples taken from the areas around the epithelial coccygeal passages in children, signs of mild chronic inflammation were detected and a large number of skin appendages were detected: deformed hair follicles with many hair shafts and sweat glands of the apocrine type which were not associated with the skin and were located deep in the formed fibrous tissue. These changes were observed in 15 children $(41.7 \%)$. However, it is interesting that in addition to the "typical" findings, it was found that all the above structural elements were located between the immature mesenchymal tissue (Fig. 2). Similar changes were not detected in control samples of pilonidal cysts from adult.

Regarding the internal structure of the pilonidal cyst, in children in 21 cases $(58.3 \%)$ it was noted that its cavity is covered with a multilayered squamous non-corneal epithelium. In contrast to these findings, in 12 adult patients 


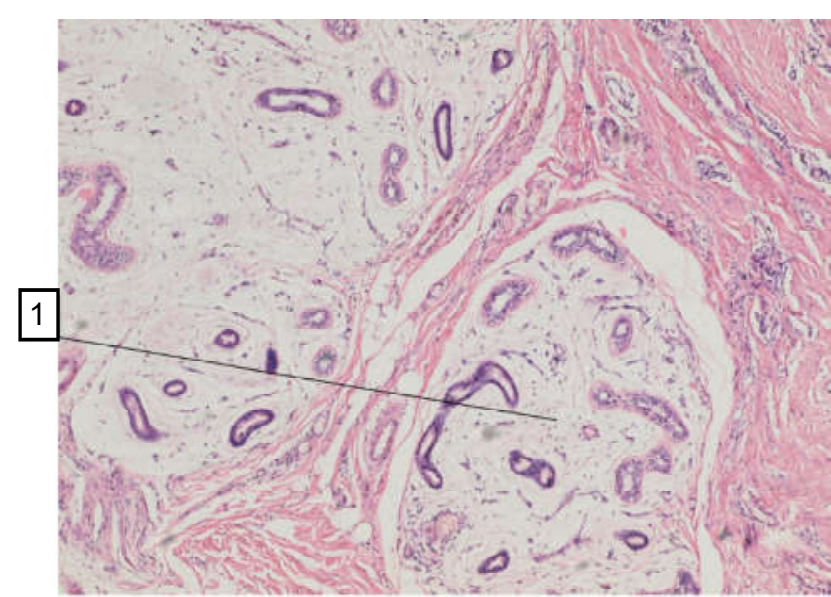

Fig. 2. Incorrectly developed skin appendages in the area of epithelial-coccygeal passages in 15-year-old girls. 1 - a large number of skin appendages (sweat glands of the apocrine type), located among the swollen immature mesenchymal tissue, with signs of minor chronic nonspecific inflammation. The skin appendages are located deep in the shaped fibrous tissue and are not connected to the skin. Hematoxylin-eosin, x100.

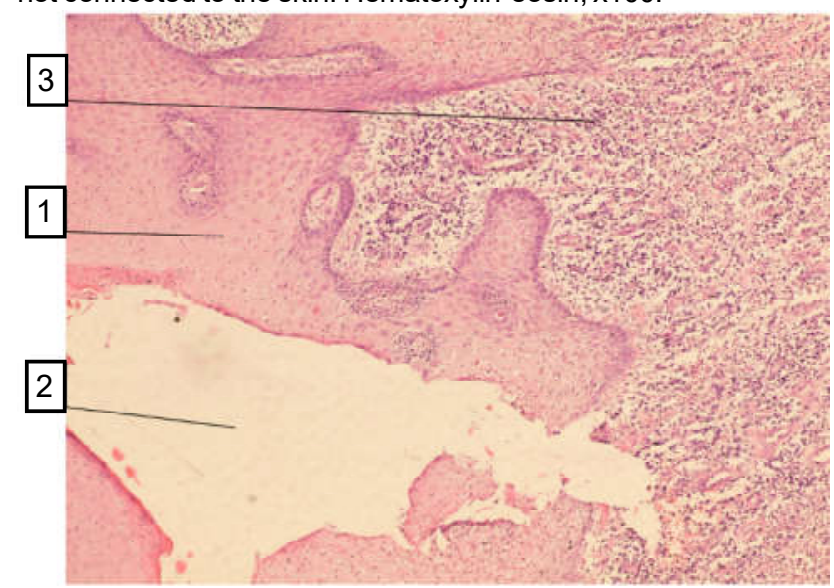

Fig. 3. Purulent-productive nonspecific inflammation in the surrounding tissues around the coccygeal cyst lined with multilayered squamous non-keratinizing epithelium. 1 - multilayered squamous non-keratinizing epithelium; 2 - the cavity of the coccygeal cyst; 3 - young granulation tissue with a pronounced leukocyte shaft with a large number of small newly formed vessels. Hematoxylin-eosin, x100.

(75.0\%) on histological specimens revealed a complete absence of epithelial lining. Instead, signs of severe nonspecific inflammation and the presence of hemorrhages into the cyst wall were detected (Fig. 3).

These changes can be explained by a longer course of pilonidal disease in adults with more relapses with inflammation and the formation of pilonidal abscess. The result may be the creation of conditions for the complete destruction of the epithelial lining of the inner wall of the pilonidal cyst with its complete desquamation and replacement by granulation tissue.

Also, in the study of epithelial coccygeal cysts in adults in 15 patients $(93.7 \%)$ their walls were lined with granulation tissue. The lumens of the latter contained fragments and whole hair shafts, exfoliated cells of the epidermis and keratinized masses. The integumentary layer of multilayered squamous epithelium around the outer openings of the fistulous passages was sharply thickened. In contrast to adult patients, similar changes were found in only 11 children $(30.5 \%)$. However, it should be noted that these patients were 17-18 years old and had frequent recurrences of the disease. It is also noteworthy that the hair shafts found did not show obvious signs of lysis (only signs of initial destruction were noted) and were associated with hair follicles. Such changes do not indicate in favor of their transdermal penetration into the cavity of the pilonidal cyst.

\section{Discussion}

At macroscopic study of a site of a pilonidal cyst it is possible to define primary fistulous courses, secondary fistulous courses and actually a pilonidal cyst with its cavity (in the presence of purulent contents in it).

Primary fistulas are mandatory components of pilonidal disease and are found in all patients, regardless of its clinical manifestations. They have a typical localization at the bottom of the intergluteal fold along the midline, often in its deepest part [5]. Histological examination of the latter revealed a typical described structure, which is presented in the form of small epithelial cup-shaped depressions. The latter have a blind end in the thickness of the dermis or subcutaneous fat and end with strands formed of connective tissue, which have the direction of the lashes to the thickness of fat and sacrococcygeal fascia (Tsema E.V.) [18]. However, in children there is a much smaller thickness of the "epithelial cups".

Secondary fistulous passages are elements that occur during the long course of pilonidal disease, accompanied by frequent periods of suppuration and spontaneous opening of the abscess. The purulent cavity due to the activity of the inflammatory process in the area of the sciatic fold increases in size. With the formation of significant pressure in it, spontaneous opening of the abscess can occur both through the primary fistulous course and through the formation of a "new" course (as a consequence of its spontaneous opening). Secondary fistulas are more often located lateral to the midline and intergluteal folds. This is due to the fact that in the latter the thickness of the dermis is slightly larger than in the areas of the medial surfaces of the buttocks, and the abscess is "harder" to open spontaneously in this area [14, 20].

As for the pilonidal cavity itself, our data coincide with other histological studies in that in most adult patients the inner wall of the pilonidal cyst has no epithelial lining and is represented by granulation tissue and immunopathological cells, which is a sign of chronic inflammation of the body. Researchers note that contents of the pilonidal cavity in adults is epithelial fragments and hair shafts of varying degrees of destruction. However, most studies did not consider the age of the patients and the 
study groups most often consisted of adults. No adult study found immature mesenchymal tissue in the wall of the pilonidal cyst, which was found in pediatric patients. Also, in more than half of the histological preparations obtained after treatment of children, the lining of the cavity of the pilonidal cyst was found in the form of multilayered squamous non-keratinizing epithelium $[4,10,11,17,18$, 19].

In the future, it is rational to study the morphological structure of pilonidal cysts in patients of pediatric age and increase the sample. This will allow to more clearly establish the cause of this pathology and will allow to develop a standardized and well-founded method of treatment.

\section{References}

[1] Akinci, O. F., Bozer, M., \& Uzunkoy, A. (1999). Incidence and etiological factors in pilonidal sinus among Turkish soldiers. Eur. J. Surg., 165, 339-342. doi: 10.1080/ 110241599750006875

[2] Bascom, J. (1980). Pilonidal disease: origin from follicles of hairs and results of follicle removal as treatment. Surgery, 87(5), 567-572.

[3] Benhadou, F., Van der Zee, H. H., Pascual, J. C., \& Rigopoulos, D. (2019). Pilonidal sinus disease: an intergluteal localization of hidradenitis suppurativa/acne inversa: a cross-sectional study among 2465 patients. British Journal of Dermatology, 181(6), 1198-1206. doi: 10.1111/bjd.17927

[4] Bosche, F., Luedi, M. M., \& van der Zypen, D. (2018). The hair in the sinus: sharp-ended rootless head hair fragments can be found in large amounts in pilonidal sinusnests. World $\mathrm{J}$. Surg., 42, 567-573. doi: 10.1007/s00268-017-4093-5

[5] Doll, D., Bosche, F. D, \& Stauer, V. K. (2017). Strength of occipital hair as an explanation for pilonidal sinus disease caused by intruding hair. Dis. Colon. \& Rectum, 60, 979-986. doi: 10.1097/ DCR.0000000000000795

[6] Doll, D., Matevossian, E., Wietelmann, K., \& Evers, T. (2009). Family history of pilonidal sinus predisposes to earlier onset of disease and a $50 \%$ longterm recurrence rate. Diseases of the Colon and Rectum, 52(9), 5-11. doi: 10.1007/ DCR.0b013e3181a87607

[7] Kallet, H. I. (1936). Pilonidal sinus the factor of adolescence. Tr. Am. Proct. Soc., 163.

[8] Karydakis, G. E. (1992). Easy and successful treatment of pilonidal sinus after explanation of its causative. Aust. N. Z. J. Surg., 62(5), 385-389. doi: 10.1111/j.14452197.1992.tb07208.x

[9] Lurin, I. A., \& Tsema, E. V. (2013). Etiology and pathogenesis of pilonidal diseases. Coloproctology, 3, 35-50.

[10] Naeem, M., Mabood, W., Imran, M., Khattak, I., \& Ahmad, M. (2019). Pilonidal disease: The changing trend in incidence based on occupation. Pak. J. Surg., 35(4), 301-305. doi: 10.1055/s-0031-1272823

\section{Conclusions}

1. Pilonidal disease should be considered as a polyetiological disease, which has its realization due to a number of congenital factors and individual characteristics of the organism, which, in turn, are embodied due to external and socio-economic factors.

2. Pilonidal disease, in our opinion, is a congenital pathology that occurs due to the combined work of environmental factors that can affect the severity of congenital features.

3. In favor of the congenital etiology of pilonidal disease testifies the presence in the pilonidal cyst in children of immature mesenchymal tissue, which in the norm is not characteristic of this age group.

[11] Muller, K., Marti, L., \& Tarantino, I. (2011). Prospective analysis of cosmesis, morbidity, and patient satisfaction following Limberg flap for the treatment of sacrococcygeal pilonidal sinus. Dis. Colon Rectum, 54(4), 487-494. doi: 10.1007/ dcr.0b013e3182051d96

[12] Nechai, I. A., \& Maltcev, N. P. (2019). Minimally invasive methods in treatment of pilonidal disease (review of the literature). Grekov's Bulletin of Surgery, 178(3), 69-73. doi: 10.24884/ 0042-4625-2019-178-3-69-73

[13] Sondena, K., Andersen, E., Nesvik, I., \& Soreide, J. (1995). Patient characteristics and symptoms in chronic pilonidal sinus disease. Int. J. Colorectal. Dis., 10(3), 39-42. doi: 10.1007/ BF00337585

[14] Stauer, V. K., Luedi, M. M., \& Kauf, P. (2018). Common surgical procedures in pilonidal sinus disease: a meta-analysis, merged data analysis, and comprehensive study on recurrence. Sci. Rep., 8, 1-27. doi: 10.1038/s41598-018-20143-4

[15] Stone, H. B. (1931). The origin of pilonidal sinus (coccygeal fistula). Ann. Surg., 94, 317-320.

[16] Tabidze, D. L., \& Saenko, V. V. (2016). Experience of radical treatment of a pilonidal cyst (epithelial coccygeal passage) with the Bascom II method (clift-lift). Surgery of Ukraine, 4, 63-66.

[17] Thompson, M. R., Senapati, A., \& Kitchen, R. B. (2010). Pilonidal Sinus Disease. Anorectal and Colonic Diseases. A Practical Guide to Their Management. Springer, 3rd ed., 373-386.

[18] Tsema, E. V. (2013). Evolution of ideas about the etiopathogenesis of pilonidal disease. Surgery of Ukraine, 2, 9-22.

[19] Tsema, E. V., \& Dibrova, Yu. V. (2013). Clinical and morphological aspects of the etiopathogenesis of pilonidal cysts of the sacrococcygeal region. Pathology, 29(3), 61-65. doi: 10.14739/ 2310-1237.2013.3.22589

[20] Zakharash, M. P., Lyshavsky, O. V., \& Oak, V. A. (2010). Ultrasonography in the diagnosis and choice of treatment tactics for epithelial coccygeal course. Surgery of Ukraine, 2, 66-71.

\section{СУПЕРЕЧЛИВІСТЬ ПОГЛЯДІВ НА НАБУТУ ТА ВРОДЖЕНУ ЕТІОЛОГІЮ ПІЛОНІДАЛЬНОЇ ХВОРОБИ \\ Конопліцький В.С., Шавлюк Р.В., Шавлюк В.М.}

Пілонідальна хвороба - патологія, яка вперше була описана понад 100 років тому. Однак, вона дотепер залишається предметом дискусій, тому що досі немає ні чіткого однозначного визначення даної патології, ні достеменно відомої іï етіології. Незважаючи на велику кількість розроблених та аргументованих теорій досі існує два протилежних погляди на причину виникнення пілонідальної хвороби. Одні науковиі є прихильниками "вродженої" теорії, інші - теорії набутого походження. Однак, це не вносить ясність у остаточну мету цих досліджень: вироблення оптимальної тактики лікування. Мета роботи - уточнення даних щодо етіології пілонідальної хвороби у дітей. Дослідження базується на результатах 
аналізу лікування 37 дітей з діагнозом "пілонідальна хвороба", що знаходились на стаціонарному лікуванні у відділенні невідкладної хіруреії Вінницької обласної дитячої клінічної лікарні, з яких хлопчики - 26, дівчатка - 11. Середній вік пацієнтів становив 16,4士0,4 роки. Гістологічні зрізи зразків тканин забарвлювали гематоксиліном та еозином. Мікроскопію та створення фотоархіву гістологічних препаратів проводили за допомогою світлового мікроскопа OLIMPUS BX 41 при збільшенні 100 та 200, у програмному середовищі "Quick PHOTO MICRO 2.3". У дослідженні виявлено, що відмічаються значні відмінності у гістологічній будові пілонідальних кіст дітей та дорослих. У пацієнтів дитячого віку знайдена мезенхімоподібна тканина, яка є нехарактерною для даного контингенту хворих. Також виявлено, що порожнина пілонідальної кісти у дітей вкрита багатошаровим плоским нероговіючим епітелієм, та у ній майже не відмічається наявність грануляційної тканини. На нашу думку, пілонідальна хвороба є поліетіологічним захворюванням, основною причиною якого $є$ вроджені особливості організму, що мають реалізацію за рахунок соціально-економічних та фракторів зовнішнього середовища.

Ключові слова: пілонідальна хвороба, діти, етіологія, морфологія.

\section{ПРОТИВОРЕЧИВОСТЬ ВЗГЛЯДОВ НА ПРИОБРЕТЕННУЮ И ВРОЖДЕННУЮ ЭТИОЛОГИЮ ПИЛОНИДАЛЬНОЙ БОЛЕЗНИ Коноплицкий В.С., Шавлюк Р.В., Шавлюк В.М.}

Пилонидальная болезнь - патология, которая впервые была описана более 100 лет назад. Однако, она до сих пор остается предметом дискуссий, ведь до сих пор нет четкого однозначного определения данной патологии, а также точно неизвестна ее этиология. Несмотря на большое количество разработанных и аргументированных теорий до сих пор существует два противоположных взгляда на причину возникновения пилонидальной болезни. Одни ученые являются сторонниками "врожденной" теории, другие - теории приобретенного происхождения. Однако, это не вносит ясность в окончательную цель этих исследований: разработка оптимальной тактики лечения. Цель работы - уточнение данных об этиологии пилонидальной болезни у детей. Исследование базируется на результатах анализа лечения 37 детей с диагнозом "пилонидальная болезнь", которые находились на стационарном лечении в отделении неотложной хирургии Винницкой областной детской клинической больницы, из которых мальчиков было 26, а девочек - 11. Средний возраст пациентов составил 16,4士0,4 года. Гистологические срезы образцов тканей окрашивали гематоксилином и эозином. Микроскопию и создание фотоархива гистологических препаратов проводили с помощью светового микроскопа OLIMPUS BX 41 при увеличении 100 и 200, в программной среде "Quick PHOTO MICRO 2.3". В исследовании выявлено, что отмечаются значительные различия в гистологической строении пилонидальных кист у детей и у взрослых. У пациентов детского возраста найдена мезенхимоподобная ткань, которая нехарактерная для данного контингента больных. Также выявлено, что полость пилонидальной кисты у детей покрыта многослойным плоским неороговевшим эпителием и в ней практически нет грануляционной ткани. По нашему мнению, пилонидальная болезнь является полиэтиологическим заболеванием, основной причиной которого являются врожденные особенности организма, имеющих реализацию за счет социальноэкономических и фракторов внешней среды.

Ключевые слова: пилонидальная болезнь, дети, этиология, морфология. 